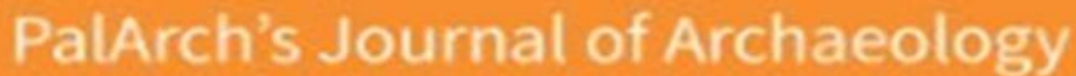

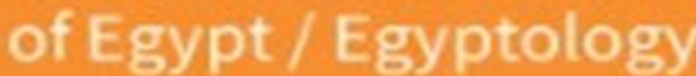

\section{Preventing Religious Radicalism on College Student in the Islamic State Higher Education (PTKIN) \\ Case Study of Islamic State University (UIN) in Indonesia}

\author{
Muhammad Sirozi $^{1 *}$, Yenrizal $^{2}$ \\ ${ }^{1}$ Department of Islamic Education Management, Faculty of Tarbiyah and Teacher Training, State \\ Islamic University of Raden Fatah Palembang, South Sumatera, Indonesia. \\ ${ }^{2}$ Department of Communication Studies, Faculty of Social and Political Sciences, \\ State Islamic University of Raden Fatah Palembang, South Sumatera, Indonesia.
}

*Corresponding Author Email: m.sirozi@radenfatah.ac.id

\begin{abstract}
Muhammad Sirozi $^{*}$, Yenrizal ${ }^{2}$-- Preventing Religious Radicalism On College Student In The Islamic State Higher Education (PTKIN) Case Study Of Islamic State University (UIN) In Indonesia -- Palarch's Journal Of Archaeology Of Egypt/Egyptology 17(6). ISSN 1567-214x
\end{abstract}

Keywords: Religion, Policy, Radicalism, Rector

\begin{abstract}
Abstrak
This study aims to determine the efforts to prevent religious radicalism in the Islamic State Higher Education (PTKIN) in Indonesia, by taking the case of five State Islamic Universities (UIN) that represent five regions in Indonesia, namely Sumatera Island, Java Island, Kalimantan Island and Sulawesi island. The efforts seen in this research are the efforts made by UIN leaders, especially the Rector, in designing, organizing and developing various academic activities for students. There are five forms of effort examined through this research, namely (1) student development policies, (2) curriculum development, (3) fostering Intra Campus Student Organizations (OMIK) and (4) coaching extra-curricular activities. Data is collected by the study of documentation, deep interviews with the Rector and other leadership elements whose main tasks and functions are relevant to student development and observation of the situation and dynamics of campus life, especially student activities. This study found that efforts to prevent religious radicalism in the UIN environment were not carried out in the form of prohibitions, not even coercive, but were carried out through passive resistance, in the form of prevention, interdiction and development of counter programs. These efforts include (1) assistance to the activities of Understanding Academic Student Culture (PBAK), (2) the development of Ma'had al Jami'ah, (3) fostering Intra-Campus Student Organizations (OMIK), (4) incorporating material on Islamic modernization into the lecture curriculum with the concept of immersion curriculum and hidden curriculum, (5) providing close mentoring and monitoring by maximizing the role of
\end{abstract}


Academic Advisor (PA) lecturers, (6) developing openness through limited dialogue and (7) developing attitudes critical and analytical through discussions, seminars and public lectures.

\section{Introductin}

The movement of violence in the name of religion, including Islam, began to show its escalation since the beginning of the 21st century, marked by the bombing of the World Trade Center Building (WTC) in New York City and Washington on September 12, 2001. The President of the United States at that time, George W Bush Junior, made a policy of preempted strike (arrest and assault without investigation) against the perpetrators of bombings and countries that allegedly supported or facilitated them (Gupta, 2008). The perpetrators of the bombings are labeled terrorists and countries that protect or facilitate them are seen as the center for terrorism (the breeding ground of terrorism). Since then the theory has become a frightening specter for the world community and the forms of vigilance and resistance carried out by the United States government were later adopted by many governments in the world. According to Wirsing's observations (2004: 8), terrorism became a feared and hunted term throughout the world. In its development, terrorism then experienced a distortion of understanding towards religious understanding. Because the perpetrators of the WTC bombings were adherents of Islam, since the incident the term terrorism seemed to be directly linked to the religion of Islam.Islam and its scholars and teachings are seen as the party that is most responsible for the rise of terrorism in various parts of the world, so that it is not only raises Islam phobia, but also causes misunderstanding of Islamic teachings. Islam is often a misunderstood religion (Wiktorowicz, 2005). Islam tends to be hated, because it is seen as a teacher of terrorism and Muslims are hostile everywhere, because they are seen as radicalists and terrorist. Such attitudes and perspectives not only have a negative impact on the atmosphere of religious life, but also on the atmosphere of social, economic and political life, both in Muslim countries and in non-Muslim countries.The attitude and viewpoint that is very negative and detrimental departs from an understanding that terrorism has a direct connection with religious radicalism, so that in everyday use "radicalism and terrorism" words seem to be one and can be used interchangeably. Terrorism is often said to be one manifestation of religious radicalism and radicalism is seen as the main root of terrorism. Anyone who is considered to have a radical religious view is seen as having the potential to carry out acts of terrorism which create fear in many parties (Mehden, 2005, Wirsing, 2004 and Langlois, 2005).

Although it often stores differences in meaning, Jati (2013) explains that radicalism, especially religious radicalism, is seen as a movement or understanding that justifies violent behavior in all ways, in the name of religion. Included in this category of understanding are suicide bombings, such as those that occurred in various places in Indonesia, 2001 WTC bombings, 2002 Bali Bombings, London subway bombs, Kuningan bombs, Cirebon bombs, New Zealand Mosque shootings and shootings in Sri Lanka, as well as various other locations. Some of these events are often seen as facts that justify 
violence in the name of religion.Despite having different contexts, the last two events in New Zealand and Sri Lanka have made radicalism and religious terrorism warm again at the international level. In New Zealand acts of terrorism are committed by non-Muslims and the victims are Muslims. In Sri Lanka, the perpetrators were identified as radical Muslim groups and the victims were also Muslims. The reasoning for the two latest acts of terrorism is of course different from the reasoning of various acts of terrorism carried out by adherents of Islam in secular Western countries whose majority are nonMuslim. Most of these actions depart from one view that Western civilization is a civilization that is dangerous and threatens global safety. This view continues to sow and foster radicalism and religious terrorism in various parts of the world (Herero 2018).

Some hard-line organizations that try to achieve their goals by means of violence or terrorism continue to emerge. One organization that has been criticized lately is the Islamic State of Iraq and Syria (ISIS) which was founded by Abu Musab al-Zarqowi and led by Abu Bakr al-Baghdadi. ISIS has become a frightening specter, not only in the Middle East region, but also in other parts of the world. ISIS has also inspired various other terror attacks (Oosterveld, 2019). All countries are now preoccupied with their respective policies and programs to be able to reduce, prevent and overcome acts of violence. Terrorism is no longer limited to issues of religion, region, or nation, but has occurred anywhere, anytime and for anyone (Herero, 2018 and Azra, 2011).In Indonesia, the intensity of the occurrence of radical actions has increased rapidly in the last 15 years. Many occurrences of a series of acts of religious radicalism certainly cause deep concern in the community and show that acts of violence in the name of religion have developed very rapidly and infiltrated various lines of life in Indonesian society, including the campus environment. If this trend is not immediately stopped, then "Indonesian Islam will surrounded by radicalism or become a radical Islamic character" (Affandy, 2016) and of course religious modernization that has long been a characteristic of Indonesian Islam will continue to weaken.

The amount of attention of the world community on the problem of radicalism and religion-based terrorism in Indonesia is really easy to understand, because the geographical and geopolitical position of Indonesia is very strategic, as a non-block country that has the largest Muslim population in the world. Muslims in Indonesia are a majority religious group amid very high cultural, ethnic and religious diversity. Radical and terrorist actions in Indonesia cannot be simplified in the context of conflicts between Islam and the West, but are very complex and have different contexts. There are some acts of radicalism and terrorism triggered by fight between Shia and Sunni groups (see Siradj, 2013 and Zainiyati, 2016), there are also, some acts of radicalism and terrorism triggered by conflict between Islam and Christianity (see Soleh, 2013 and Jonathan, 2013).According to BNPT (2016) radicalism is the embryo of terrorism. Radicalism is an attitude that craves total change and is revolutionary by overturning the values that exist drastically through violence and extreme actions. There are several characteristics that can be 
recognized by radical attitudes and understandings. The first feature is intolerance (unwilling to respect the opinions and beliefs of others. The second characteristic is fanaticism (always feeling right on their own, assuming someone else is wrong). The third characteristic is being exclusive (distinguishing themselves from Muslims in general) and the fourth feature is revolutionary (tending to use violent means to achieve goals). Radicalism can be divided into two parts, namely radicalism of thought and radicalism of action. Radicalism of thought is radicalism which is still in the form of ideas that consider their views to be the most correct, intolerant and tend to be critical in thinking. Radicalism in action is a continuation of the formed mindset (Asyari, 2018) According to the Director of Prevention of BNPT, Hamli (2019), radicalism can be seen from three stages, namely, intolerance, radicalism and terrorism. This intolerant attitude can develop further if left without prevention (see Zada, 2009).

All radicalism and terrorism actions should become a concern to all parties who have authority in fostering and securing the community. But what is very concerning is the fact that acts of terrorism and religious radicalism in Indonesia involve many young people in the age of higher education, with an age range ranging from 20 to 40 years as executor. In 2018 the Indonesian National Counter Terrorism Agency (BNPT) arrested suspected terrorists in Riau, allegedly the perpetrators were students at Riau University. Research conducted by the State Intelligence Agency (BIN) in 2017 is quite surprising, that $39 \%$ of students in Indonesia have been exposed to radical understanding or religious radicalism. Likewise other research from the BNPT concluded that radical understanding had already entered campuses. Stronger data emerged from research conducted by the Center for Islamic and Community Studies (PPIM) Syarif Hidayatullah State Islamic University 2017 and 2018 (Saputra, 2018) which revealed that $58.5 \%$ of students in Indonesia had radical religious views, and $51 \%$ have intolerant opinions on the flow in Islam. Several other studies also revealed the facts of the spread of radical ideas in the campus environment (Dja'far and Nuraini, 2016, Ali, 2017).

Some of these studies also reveal that religious radicalism does not only infiltrate students, but also infiltrates lecturers. It was also revealed by several studies that the entry points that were used by radical groups in the campus environment were student organizations. These facts are certainly important to be of concern to the higher education authorities in Indonesia and the managers of higher education institutions, considering that the campus is an educational arena, where prospective educators and nation leaders are spelled out in their mindset, attitude and mentality.

A more surprising fact is that radicalism and terrorism have not only succeeded in infiltrating State Universities (PTN) campuses, but also in the campuses of the State Islamic Higher Education (PTKIN). For example, the Book Bomb case in Jakarta involved an alumnus of Syarif Hidayatullah UIN, Jakarta. The research conducted by Khozin in 2013 more clearly revealed the facts of the infiltration of religious radicalism into the PTKI campus environment. Khozin (2013) revealed three things related to radicalism among 
PTKI students. First, there is a tendency towards radical religious attitudes of PTKI students, but is still of a low level. Second, there is a tendency for sectarian ways of thinking, especially related to the positivation of religious norms in state life. Third, the tendency of political religious orientation and fourthly, there is a tendency for support for the use of violent media to actualize religious messages.

The facts revealed through the above studies certainly contradict the ideal characteristics of religious life that are expected to develop in Indonesia, namely moderate religious life. In particular, these facts are very contrary to the vision and mission of Indonesian Islamic Higher Education (PTKI). The Strategic Plan of the Directorate of Islamic Higher Education Ministry of Religion of Indonesia in 2015-2019, clearly stated that the vision of PTKI development is "Realizing Islamic Religious Higher Education as a World Referral".As a religious higher education institution, PTKI is expected to play an important role and take responsibility in various efforts to prevent the development of religious radicalism movements. All members of the academic community, especially students, must be introduced and familiar with inclusive and moderate understanding, thought patterns, attitudes and religious actions, not exclusive and intolerant religious thoughts and movements. Of course these roles and responsibilities are very heavy and not easy to run, because there are many variables that are related and can influence and shape radicalism thoughts and movements. According to Saifuddin (2011), radicalism movements are often related to ideology, economy, hatred and displeasure that have grown and developed for a long time. From the many variables that exist, according to Saifuddin (2011), ideology is one variable that is difficult to enter and change without the existence of approaches, processes and special treatment.

Modernization in higher education will only be realized if PTKIN is able to introduce moderate religious patterns and prevent the development of radical religious patterns. All PTKIs are certainly expected to be the center of moderate Islamic nursery (the breeding ground for moderate Islam), not the center of the radical breeding ground (the breeding ground of Islamic radicals). Realizing this hope is the responsibility of all stakeholders of Islamic higher education in Indonesia, especially the rector. He required to do their best in an effort to prevent the development of radicalism and to foster religious moderation among the entire academic community, especially students. This task is certainly not easy, because the seeds of radicalism do not only come from the campus environment, but from various religious radicalism networks that are outside the campus (see Syaifudin 2011).

This research departs from three basic assumptions. First, that UIN has a big role and responsibility in shaping the attitudes and religious behavior of the community, because UIN is the largest and relatively most advanced PTKIN cluster, which is expected to be the locomotive for other PTKIN developments and an example or direction for the development of studies and religious activities. Second, that UIN is expected to be able to produce graduates who will become leaders in various fields of people's lives, especially in the religious fields. Third, that religious radicalism has become 
one of the symptoms of religious life that is very worrying for many countries, because without adequate supervision and control religious radicalism can have a very destructive impact. Fourth, data published by various institutions shows that religious radicalism has grown and developed in various environments and institutions in the community, including institutions of higher education and PTKI.

An important change that occurred in PTKI and potentially changed the style of thinking and orientation of religious movements among academicians was the change in the institutional status of the Islamic State Institute (IAIN) to become a Islamic State University (UIN). Since 2001 until now there have been 17 IAINs that have switched their status to UIN ${ }^{i}$. In the context of prevention of religious radicalism, changes in institutional status from IAIN to UIN are very important, because these changes have substantive implications for academic programs which in many ways can change the eco-system of religious thought and movement in PTKI and its community environment.

Some noteworthy implications of the change in the institutional status of PTKI from IAIN to UIN, among others, are first, the presence of faculty and general study programs. When it was an IAIN, PTKI was already used to the presence of general sciences, but it was still very limited to the tadris program and the General Basic Course (MKDU) which semester credit units were very limited. After switching to UIN status, some PTKIs began to open faculties and general study programs which of course demanded more semester credit units (SKS) for general or non-religious fields of study. The second implication is the increase in the number of educators or lecturers and education staff with educational backgrounds and general or non-religious fields of expertise.

The third implication of the change in institutional status of PTKI from IAIN to UIN is the increase in institutional parentages. When it was an IAIN and did not yet have a faculty and general study program, PTKI's academic service process was fully in the Ministry of Religion, with quality standards and accreditation as applicable to the National Accreditation Board of Higher Education (BANPT).

The fourth implication of the change in the institutional status of PTKI from IAIN to UIN is the increase in academic service quality standards, because it is not only required to follow academic service standards as applicable in the PTKI and BAN PT Directorate, but also required to follow academic service standards as applicable in the Ministry of Research, Technology and Higher Education.

The fifth implication that arises from changing the institutional status of PTKI from IAIN to UIN is the change in student social, economic and educational background. When it was an IAIN, most of the students came from lower middle class families and their high school education mostly came from Islamic boarding schools, Madrasahs and schools in the area. After changing into UIN the students are vary from middle to upper families and Madrasah graduates and excellent schools, more and more are continuing their studies at PTKI. 
The sixth implication of changing PTKI status from IAIN to UIN is the change in the background and academic experience of lecturers and employees. When it was an IAIN, most of the teaching and education staff came from the PTKI, with a background in religious education. After becoming a UIN, more and more educators and education staff came from public or PTN colleges. This change certainly makes the profile of Human Resources (HR) in the UIN are more heterogeneous and makes the atmosphere and work environment in the academic and non-academic fields are more dynamic and varied.

With these six implications, the change of status from IAIN to UIN brought many changes, including changes in the religious environment, from religious environments that tended to be homogeneous to heterogeneous religious environments, both in the level of religious knowledge, patterns of worship practices, and the depth of faith. This heterogeneity opens many doors or routes that can be used to enter religious life of members of the academic community, especially students. It is very wrong if we assume that the development of faculties and general study programs along with lecturers and employees with general education background reduces the dynamics or passion of religious life in the UIN environment. On the contrary, the meeting between various religious disciplines and general disciplines along with their respective students and lecturers, increasingly made the atmosphere of religious life in UIN campuses more "colorful" or variative and dynamic. It is this variation and dynamics which in turn makes UIN become increasingly important in the discourse of development and prevention of religious radicalism today and in the future.

Although it has been running for 18 years, religious formation in general and prevention of religious radicalism in particular has become very important in the era of UIN, because the transformation of IAIN into UIN, according to Hidayat (2015), led to "uncertainty" in campus circles. Meetings and links between various thoughts, organizations, and religious movements naturally lead to conflict of authority and conflicts of interests that can lead the division and foster radical attitudes, thoughts and actions. The meeting and engagement can even lead to stuttering and surprise at the changing in the religious environment, especially among lecturers called "seniors" and "juniors".

On the other hand, many people think that PTKI, especially UIN, is a gathering place for Islamic scholars who have extensive knowledge, so that they can provide exemplary and coolness to society. This view is certainly not entirely relevant, because currently in PTKI, including UIN, there are various levels of knowledge, insights and religious orientation. Even though it has been developing for more than a decade, the existing UIN is still faced with various problems related to understanding and practicing security. The controversy on banning the burqo at IAIN Bukit Tinggi, UIN Sunan Kalijaga Yogyakarta and at other PTKIN, is an example of the dynamics of religious understanding which still varies greatly in the UIN environment.

As explained above, this paper presents and explains data related to the efforts or steps taken by PTKIN leaders, especially the Rector, in preventing 
the growth of religious radicalism among students. It is believed in this paper that with his authority the Rector is a determinant factor in designing, forming and developing religious traditions and culture on PTKI campuses. The data presented in this paper are the results of research involving five UIN Rectors, with three main questions, namely (1) how do UIN Rectors view the development of religious radicalism in general and in particular student environments, (2) what are their views on causes and the impact of the development of religious radicalism among students, (2) what policies and programs they create or develop to prevent the growth of religious radicalism among students. The five UIN Rectors chosen as respondents in this study are; Rector of UIN Sultan Syarif Qasim (Susqa) Riau, Rector of UIN Syarif Hidayatullah (Syahid) Jakarta, Rector of UIN Sunan Kalijaga (Suka) Yogyakarta, Rector of UIN Antasari Banjarmasin, and Rector of UIN Alauddin Makassar. The five respondents were chosen and determined with consideration of the representation of the NKRI region, namely the territory of Eastern Indonesia, Central Indonesia and Western Indonesia.

\section{Method and Approach}

This research is a qualitative study that uses a case study model (Creswell, 1998). The case study approach was chosen in this study, with three main considerations. First, the problem of radicalism is not a general problem, but it is a special problem involving certain individuals and groups, which requires a specific method or approach, to be able to understand it. Second, UIN is a specific religious higher education entity, which has many differences both academically and non-academically with other higher education institutions, both within the Ministry of Religion, such as the Islamic College (STAI) and State Islamic Institute of Religion (IAIN), or Public University (PTN) or Private University (PTS) is in the Ministry of Research, Technology and Higher Education. Third, the problem of religious radicalism is a complex problem, which is not only manifested in the form of religious movements, but also in the form of beliefs and thoughts, so that the disclosure requires deep data mining techniques, as is commonly used in case studies, namely in-depth observations and interviews (deep interviews) (Maseleno et al., 2019).

With these three considerations, the data collection for this study was carried out by using a deep interview method to the Rector, observing the educational situation in each campus where the Rector became an informant and collecting library materials related to data needs. In addition, this study also uses a library study approach, specifically to look for various references related to data on religious radicalism in general, such as in Indonesia and the world also on UIN campuses in particular. In-depth interviews were conducted to obtain data on the point of view of UIN Rectors regarding religious radicalism, the potential for its spread in the campus environment, especially students and what strategic efforts they have and will do to prevent the spread of religious radicalism in the campus.

Interviews was using open questions, the implementation of interviews is supported by the existence of interview guides, which are specifically made 
for research assistants, so that the questions they submit and the data they obtain are relevant to the needs or research questions. Although the main informants in this research were the Rector in five UINs that were sampled, interviews were also conducted with several campus officials whose main tasks and functions were relevant to the field of student affairs, such as the Vice Rector for Student Affairs, Dean, Deputy Dean of Fields Student Affairs, administrators of student organizations, and several parties who are considered to understand student affairs on campus.

The observations made on the educational activities carried out the condition of student activities in each Higher Education, methods of formation and regeneration applied in Intra-Campus Student Organizations (OMIK). The process of observation is carried out in all campuses sampled and takes 30 days. As with interviews, the implementation of observations is also supported by observation guidelines prepared according to the research questions. In accordance with the characteristics of qualitative research, instrument validation takes place when data search activities are carried out. In its implementation the instrument is adjusted to the situation at the time of observation, while still adhering to the research questions that have been made. To conduct interviews, researchers went to each campus chosen as the location of the study and involved the speakers who were there.

With this method the collecting required data was succeeded, which revealed the attitudes, thoughts, policies and programs carried out to prevent the growth of radicalism among students. The data is then processed and analyzed, and then becomes material in explaining the efforts or strategic steps taken by the Rector in an effort to prevent the development of religious radicalism in the student environment. Analysis was carried out using the SWOT framework (Bryson, 2005) which included internal Strength, Weakness (internal weakness), and external aspects or called Oppurtunity and Threats.

The results of the analysis with the SWOT framework were then assessed and interpreted to reveal strategic efforts carried out by UIN's Rector in preventing the development of religious radicalism and to develop recommendations for strengthening efforts to prevent religious radicalism in the PTKI campus in general and UIN campuses in particular. Specifically, data analysis examines the strength of strategic efforts that have been carried out by UIN's Rector in preventing the development of religious radicalism among students and what the situation of the campus is in particular and the community in general which according to them contributes to the birth of these strategic efforts.

\section{Discussion}

\section{Rector's perspective}

A policy should depart from understanding the problem. Furthermore understanding will bring forth policies that can be anticipatory or solutive (Dunn, 1999). Various policies made by the Rector in an effort to prevent or anticipate the development of religious radicalism among students, are actually not rooted in the issue of radicalism itself, but are closely related to the Rector's 
perspective on various aspects of religious radicalism. Radicalism can develop because of certain ideologies, understanding certain religions and religious insights or certain nationalities. This research reveals that the policies and efforts of the UIN Rector in preventing the development of religious radicalism among students are preventive, not curative policies and efforts. For UIN Rector, radicalism grew not because of ideological factors, but because of errors in understanding religious texts and the lack of religious and national insight. The foundation of the policy or program made by the Rector of UIN in preventing the development of religious radicalism among students was not directed at radicalism, but in the development of student character and fostering understanding and insight into their religion and nationality. The policies taken are not directly correlated with the occurrence of radicalism, but are believed to have indirect implications for the emergence of radical movements.

It can be said that the policies and efforts to prevent the development of religious radicalism among students depart from their understanding of the risks that can be generated in the event of religious radicalism among students, both on campus life in particular, and on religious also on national life in general. What was done by the Rector of UIN in preventing the development of religious radicalism among students was in line with the perspective of risk management which emphasized the importance of problem mapping along with their respective risk levels, which were overcome by a comprehensive and systematic management approach (Fahmi, 2011). In this context it can be said that the policies and efforts made by the Rector of UIN in preventing the occurrence of religious radicalism among students are efforts to overcome or prevent the risk of radicalism among students.

As explained at the beginning of this paper, one of the focuses of the study conducted was to look at the perspectives of UIN Rector on the dynamics of the development of religious radicalism in thinking, attitudes and movements in the particular campus environment and society in general. In the effort and process of preventing religious radicalism, the perspective of the Rector is very important, because their perspective will determine the intensity and quality of the efforts they undertake to prevent the development of religious radicalism in the campus. Their perspective as a top leader and decision maker on campus about religious radicalism will determine the policies and programs that they run to prevent the development of religious radicalism in the campus environment in general and in the student environment in particular. As the top management, the Rector has great power to determine the direction of the institution he leads. The key to success in improving the quality of human resources in educational institutions is largely determined by leaders and managerial leaders.

In particular, this study looks at the perspectives of UIN Rector on religious radicalism from two sides, namely the mindset on radicalism and the action on radicalism (see Asyari, 2018). It is assumed in this study that radical thought patterns do not necessarily develop into radical actions or movements are assessed in the form of physical activity. This study found a similarity in 
the views of the UIN rector about religious radicalism thoughts and movements in general and in the campus environment in particular.

According to Prof. Dr. Mujahiddin, M.Ag., Rector of UIN Susqa Riau, radicalism is identical to the behavior of religious violence which is motivated by certain religious understandings. According to the Mujahiddin, there are two dimensions of understanding that can trigger religious radicalism, namely the simplicity of religious understanding and an anti-establishment economy. Radicalism, he added, is not in the ideological realm, but rather is the result of a dialectic between external influences and religious knowledge. Among students, Mujahiddin explained, radicalism can grow and develop through a kind of indoctrinization by using "brainwashing methods", so that students who are dragged into religious radicalism movements are not caused by a single belief, but are only deluded by the process of indoctrination, so it is possible can be prevented. In the view of the Mujahiddin, at this time the phenomenon of religious radicalism was in the state of emergency and of course urgently needed appropriate precautions and safeguards if not addressed from now on.

Meanwhile Professor Dede Rosyada, MA., Rector of the Syahid UIN Jakarta, has a somewhat different view. According to Dede, radicalism or violence in the name of religion is a problem that has long been echoed and has long historical roots, with genealogy clearly visible. Dede's view seems to be in line with Azra (2011) 's view that religious radicalism has long roots in Islamic history, starting from the Khawarij movement at the time of Ali bin Abi Talib, then Wahabiah in the 19th century. Religious radicalism, in Dede's view, is identical with the action justifies the methods of violence in religion, both physical and non-physical, which have nothing to do with the problem of theology, even ideology. Religious radicalism, he explained, was triggered by wrong understanding, which was then considered correct. Dede considered that currently the problem of religious radicalism is already worrying. Therefore, he stressed, steps must be anticipated as early as possible, so that religious understanding-based acts of violence do not strengthen again (see also Rosyada, 2018). According to Rosyada (2018), at UIN Syahid Jakarta these anticipatory steps have been carried out at the personal and institutional level. Institutionally, he explained, the leadership of UIN Syahid Jakarta had affirmed the anti-radicalism's attitude and views through slogans that were continuously socialized, namely Inclusiveness, Tolerance, Pluralism. Rosyada (2018) explained that these three values must color and become the spirit of all academic and non-academic activities at the Syahid UIN campus in Jakarta. Lecturers, students, employees and anyone who claims that the UIN Syahid academic community is required to understand these three core values. The slogan, said Rosyada (2018), is an antidote that is believed to be able to make understanding and movements of religious radicalism unable to develop within the campus of the Syahid UIN Jakarta.

The Rector of UIN Suka Yogyakarta, Professor Yudian Wahyudi, argued that religious radicalism must be prevented as early as possible, and this nation could not possibly consider it non-existent. At present, according to Yudian, the conditions of religious life in Indonesia are worrying, because of 
the many religious thoughts and movements that lead to radicalism. In Indonesia, said Yudian, religious radicalism not only justifies acts of violence in the name of religion, but also leads to efforts to replace the state philosophy. This situation, Yudian stressed, must be aware of, so as not to appear in the community. Yudian is in line with Dede and holds that religious radicalism is only a matter of error in understanding religious teachings, not in the substantive region. In his journey, firmly Yudian, religious radicalism is often deflected into ideological beliefs, so that the impact is often very extraordinary on the order of religious life of the people. For Yudian, the root of the problem of religious radicalism is limited religious insight (Wahyudi2018). In an effort to prevent the development of radicalism among students, Yudian is often very assertive in prohibiting religious practices and symbols which according to his judgment lead to religious radicalism. In 2018, for example, Yudian in his capacity as Rector issued a letter prohibiting the use of burqo on campusii, although with certain considerations the ban was finally revoked. Of course there were many considerations that caused the ban to be revoked. But it should be suspected that the revocation was due to pressure from radical groups. If this is true, it means that the understanding and movement of religious radicalism is indeed quite strong and should be a concern of all parties.

Meanwhile, the Rector of UIN Antasari Banjarmasin, Professor Dr. Abdul Mudjib, MA., (2018), agreed with other UIN Rector, that religious radicalism is an issue that must be observed and watched out for. Religious radicalism, according to Mudjib, is related to violent behavior in religion, seeing others as wrong and only the right group. In Mudjib's view, the understanding and movement of religious radicalism is a dangerous thing for the life of the nation and state, especially if the understanding and movement enter into life and student activities. According to Mudjib, the disseminators and religious radicalism movements often take advantage of new students who are often upset when they have to adapt to the campus world. Therefore, Mudjib argued, efforts to prevent the spread of ideology and religious radicalism movements need to be focused on new students, by providing guidance, direction and assistance, so that they do not bother entering the campus world and have a clear academic and religious orientation.

Professor Dr. Musafir Pabbari, MA., (2018) has a view that is in line with Mudjib. For Musafir, religious radicalism is a movement that must be prevented and prohibited, especially in the campus world. But, according to Musafir, radicalism must be distinguished from anarchist behavior. Anarchism tends not to have ideological nuances, but rather in expressions in a mere movement. The radicalism, according to Musafir, is an anti-NKRI movement, Pancasila, the 1945 Constitution, and Bhineka Tunggal Ika. In the context of ideology and understanding of religion, according to Musafir, radicalism will seriously threaten socio-cultural and political stability. If it develops in student life, Musafir explains, the effect can be enormous. Therefore he has the same view with Mudjib, that the spread of ideas and religious radicalism movements among students must be done as early as possible. 
The views of the UIN Rector summarized from the results of the interviews as outlined above show a number of important things. First, there are similarities in views about what is meant by religious radicalism. For them religious radicalism is a religious movement or action that tends to want to achieve its goals by using methods of violence. Secondly, they have a relatively similar assessment, that the understanding and movement of religious radicalism has expanded into all lines of people's lives, including the campus environment, so that it is worth worrying about. Third, most of the four out of five Rector interviewed agreed that the trigger for the development of religious radicalism among students was a narrow and erroneous religious view. They believe that religious radicalism in Indonesia, as written by Azra (2011), developed, especially among young people, more in understanding literal, not substantial texts. Only the Rector of UIN Makassar, Musafir, saw radicalism among students as an ideological phenomenon. Fourth, that religious radicalism is not a contemporary phenomenon, but has a long historical root in the history of the development of Islamic civilization. Table 1 below provides a brief overview of the UIN Rector regarding developments, the scope of threats and the nature of religious radicalism also the urgency of its prevention.

Table 1. The Rector's views on Religious Radicalism

\begin{tabular}{|c|c|c|c|}
\hline Respondents & $\begin{array}{c}\text { Urgency for } \\
\text { Prevention }\end{array}$ & Types \& Scope of Threats & $\begin{array}{c}\text { The Nature of } \\
\text { Religious } \\
\text { Radicalism }\end{array}$ \\
\hline Rector UIN Susqa Riau & Urging & $\begin{array}{c}\text { NKRI, Pancasila, religious } \\
\text { harmony, national stability }\end{array}$ & Non-ideological \\
\hline Rector UIN Syahid Jakarta & Urging & $\begin{array}{c}\text { NKRI, Pancasila, religious } \\
\text { harmony, national stability, a } \\
\text { culture of violence }\end{array}$ & Non-ideological \\
\hline $\begin{array}{c}\text { Rector UIN Suka } \\
\text { Yogyakarta }\end{array}$ & Urging & $\begin{array}{c}\text { NKRI, Pancasila, religious } \\
\text { harmony, national stability, } \\
\text { campus stability }\end{array}$ & Non-ideological \\
\hline $\begin{array}{c}\text { Rector UIN Antasari } \\
\text { Banjarmasin }\end{array}$ & Urging & $\begin{array}{c}\text { NKRI, Pancasila, religious } \\
\text { harmony, national stability, } \\
\text { weakened local traditions }\end{array}$ & Non-ideological \\
\hline $\begin{array}{c}\text { Rektor UIN Alauddin } \\
\text { Makassar }\end{array}$ & Urging & $\begin{array}{c}\text { NKRI, Pancasila, religious } \\
\text { harmony, national stability, } \\
\text { division among students }\end{array}$ & Ideological \\
\hline
\end{tabular}

Source: Analysis of research data, 2018

Various steps and strategies have been done, considering many factors that can foster religious radicalism among students. Although the data on radicalism actions on UIN campuses is still very minimal, the Rector are of the view that the data presented in Table 1 above show that all UIN Rector indicated that religious radicalism was related and even identical to violent behavior and caused various threats. According to them, religious radicalism can create social political instability and if ignored, it can even threaten the 
integrity of the Unity Republic of Indonesia and the Pancasila. In their view, ignoring or belittling the development of religious radicalism and allowing it to continue to strengthen is a very big gamble for the future of Indonesia. The Rector of UIN agreed that the prevention of the development of religious radicalism among students "urged" to be done, using efforts to prevent religious radicalism on each campus was urgent to do, given the many threats from radical groups outside the campus who wanted making the campus the target for socializing their radical views.

The concerns of the UIN Rector are not excessive, because according to Nur Syam (2018) the emergence and strengthening of religious radicalism will have an effect on many things, for example, there has been a reduction in the understanding of religion in society, including among students. This reduction in understanding of diversity, according to Nur Syam, moves from understanding that teaches peace, becomes an understanding that is based on violent and intolerant movements. In the view of Nur Syam, religious radicalism is a social response to the social reality constructed as "deviating" from the true teachings of religion. The issues developed are related to western injustice towards Islam, modernization which is misguided and the failure of the secular government to organize and build its society.

Until now, the Rector said that religious radicalism among UIN students, especially those in the form of physical actions, had not yet occurred. Even if there are cases that carry the name of a particular UIN, the culprit is actually someone who is no longer a student or an alumnus. The case of Pepi Fernando involved in the Tangerang bombing and book bombing is a fact, where he was already an alumnus from the Syahid UIN Jakarta. But this case still involves the educational process that previously took place in each UIN. However, according to Azra (2011), cases of religious radicalism tend to be easier to enter and expose students from Public Higher Education (PTN) than they do. This note is in line with the BNPT analysis which states that nonreligious campuses or PTNs are the most vulnerable to the influence of religious radicalism. Various cases of religious radicalism involving elements of students or alumni do come from PTN campuses. The most recent example is the case of religious radicalism that took place at Riau University in 2018.

The Rector or UIN leaders have the same view, that the emergence of radicalism among students is caused by two main things, namely low religious insight and lack of national insight (Mujiburrahman 2018, Rosyada 2018, Pabbarani 2018, Wahyudi 2018 and Mujahiddin 2018). The lack of religious insight, according to the UIN Rector, is due to the increasing number of UIN students who have a non-religious education background, as a logical consequence of the many faculties and non-religious study programs that accompany status transfer from IAIN to UIN. As for the lack of national insight, according to the Rector, many are caused by socio-political dynamics as well as patterns of primary and secondary education that are less intense in instilling national insights into students.

The Rector of UIN agreed that the lack of religious insight and limited national insight were the core of the problems that led to the emergence of 
religious radicalism, which was related to various other problems in the campus environment. The first problem is student anxiety. Students, especially new students who are troubled in adapting to the campus environment, are upset about the challenges of the study, upset about friendships, and upset about the future, giving space for the influx of radical thoughts and religious activities. The second problem is the pattern of guidance and activities of student organizations (Ormawa), because Ormawa has its own mechanism in carrying out its activities, so it often escapes monitoring and supervision of campus leaders, so that young student activities are infiltrated or intervened by alumni or religious leaders and community leaders, both those with radical and non-radical religious views. The third problem is that many government social, economic, religious and political policies are not in line with the idealism of the students. The fourth problem is the problem of curriculum and learning methods that lack the portion of material needed to prevent the development of religious radicalism thinking and activities, so that students get more teaching and religious education from other sources, not from their lecturers.

\section{Prevention Policies and Programs}

In line with their concerns about the threat of religious radicalism among students, the Rector of UIN have made several policies and organized several programs which are considered to counteract the influence of religious radicalism among students.

\section{Utilization of Introduction to Academic and Student Culture (PBAK)}

One of the policies and efforts made by the Rector of UIN to prevent the development of radical patterns and patterns of action among students is to utilize PBAK events to convey messages or material that can foster a sensitive and critical attitude towards radical religious thoughts and actions and introducing moderate understanding, mindset and patterns of religious activity. This effort is carried out by presenting national and religious figures as resource persons. They were asked for various insights and experiences about how bitter it was to deal with religious radicalism which tended to justify violence and conflict and the importance of promoting inclusive and moderate religious attitudes, which are essential in realizing harmony and peace.

\section{Making the Ma'had al Jami'ah Program Effective}

In addition to through PBAK activities, the Rector of UIN also take preventative measures against the development of religious radicalism among students through the activities of Ma'had al Jami'ah. Although the capacity and intensity of Ma'had al Jami'ah's activities in various UINs are different, the Rector and other UIN leaders agreed to use them not only to develop religious knowledge in general, but also to introduce and instill inclusive religious knowledge, understanding and moderate. All new students, both those who live in dormitories and those who do not stay in the dormitories, are required to take 
part in intensive religious and foreign language activities, at least in the first year.

At UIN Antasari Barjarmasin, for example, the Education program in Ma'had al Jami'ah is held in the form of intensive religious learning for new students in turns within a certain period of time, according to the capacity of available dormitories (Mujiburrahman, 2018).

At UIN Suka Yogyakarta, because there are no dormitories available for Ma'had al Jami'ah, Ma'had's activities are carried out through collaboration with Islamic boarding schools around the campus. By the Rector, Yudian Wahyudi, this program is often referred to as the term Pesantrenization. Ma'had's activities, according to Yudian, are reserved for new students who are not from religious high school (Wahyudi, 2018).

At UIN Alauddin Makassar, the development of new students was carried out in the form of a combination with a capacity building program which he called the Capacity Building Program Training (CBPT). As the name implies, this program equips new students with the knowledge, attitudes, characters and insights that they need to succeed in study and become quality graduates, who have high competitiveness in the community (Pabbarani 2018). Through CBPT activities, the Rector and other leaders of UIN Alauddin Makassar maximize religious, national and character education programs for new students.

In all UINs, Ma'had is not just a dormitory to stay overnight, but is a strengthening educational institution equipped with a separate curriculum managed by a chairman ma'had. This model is a standard model that applies nationally and has been implemented in all UIN, as an implementation of the policy of the Directorate of Islamic Higher Education Ministry of Religion of the Republic of Indonesia. In addition to enriching and strengthening religious knowledge and skills, education in Ma'had is also specifically expected to be a center for fostering a moderate religious attitude, to fend off the development of religious radicalism.

\section{Optimizing the Role of Academic Supervisor Lecturers}

The main task and function of Academic Advisors (PA) is to provide academic guidance to students, so that they can adapt to standards, ethics, discipline and academic culture in higher education, so that they can participate in various academic activities well and graduate to become qualified graduates. Related to efforts made to prevent the development of religious radicalism among students, the Rector of UIN gave special assignments to the lecturers, so that they would take advantage of the moment of academic guidance to remind students of their guidance on the potential and dangers of religious radicalism. In the expression of the Rector, this program is called an intensification and strengthening program of academic guidance.

\section{Special Coaching Program}

Special student coaching programs are conducted at UIN Antasari Banjarmasin. This program is carried out by opening the Student Interest and 
Talent unit model, with the main goal being to increase the creativity and spirit of student entrepreneurship. The aim of this program, according to Mujiburrahman, is to prevent the occurrence of unrest in students and to strengthen the direction of the career and future that it will take.

\section{Supervision of Ormawa}

The Rector of UIN also made efforts to prevent the development of religious radicalism among students by intensifying supervision and guidance towards students. Guidance and supervision of Ormawa is carried out by controlling all student activities. All proposed activities are strictly selected, including the names of the speakers to be invited. Also included as part of the implementation of control of Ormawa is to apply the standard requirements in the process of recruitment of management and membership of each student. This model of coaching and supervision is carried out on all UIN campuses. The Rector believe that the entrance to radical understanding is very possible from Ormawa. Community networks with outside parties are very vulnerable to the entry of new understandings.

\section{Lecturer Coaching and Supervision}

Lecturers and students have a very important relationship. This relationship usually goes through a process of guidance, consultation and lectures. Therefore, it is not surprising that one of the steps to prevent the development of religious radicalism among students is to provide guidance and supervision on the activities of the lecturers. It is believed that the thinking patterns and attitudes of the lecturers influence and shape students' mindsets and attitudes. Lecturers who have a radical mindset certainly have very broad and open opportunities, to influence the thinking patterns and attitudes of their students. In addition to observe the daily movements of the lecturers, this effort is also carried out by closely monitoring the lecture recruitment process. That is, the lecturer selection process gives attention to the attitudes and religious behavior of prospective lecturers. Fostering the attitudes and mindset of the lecturers was also carried out by upholding the lecturer code of ethics. The series of coaching and supervision of the lecturer is carried out by all the leaders, namely the Rector, Vice Rector, Head of Bureau, Deans, Deputy Deans, Head of Study Programs, Secretary of Study Programs and other relevant leadership elements.

\section{SWOT analysis}

The following analysis addresses each of the Rector's policies, according to the context that what is done is part of management to reduce risk. The analytical framework uses SWOT which will later be able to bring up policy recommendations, as add-ons of the policies that have been made.

Internal Strength. Internally, each UIN has the authority to make policies, as well as policy support from the Directorate of Islamic Higher Education (Diktis) of the Indonesian Ministry of Religion (Salim2018). This affirmation is also reinforced by the Strategic Plan of the Ministry of Religion 
of 2015 - 2019 and the Strategic Plan of the Directorate of Islamic Higher Education, Directorate General of Islamic Education, Ministry of Religion, one of which mentions that aspects of religious education should be a point of concern. Internally, the Rector of UIN have their own power, in the form of authority to regulate and determine policies in their respective institutions. Having a full priority to formulate policies and programs that are deemed necessary and relevant, to prevent the development of religious radicalism among students. This authority is also clarified and confirmed in the Statutes and Organizations and Work Procedures (Ortaker) of each UIN determined through a Decree of the Minister of Religion. Other internal strengths possessed by the UIN Rector are the authority to open faculties and general science study programs according to their respective needs and conceptions. With the spirit of the integration of science, for example, the Rector of UIN can encourage the realization of connectivity and relations between the general sciences and religious sciences through curriculum engineering, learning strategies and empowerment of educators or lecturers. This religious-general scientific connectivity and relation, according to Azra (2011), can encourage the occurrence of scientific and religious dialectics between faculties and study programs with the social reality of today's society and various moderate religious understandings. This dialectics is expected to encourage connectivity and relations between the general sciences and religious sciences, in order to encourage the development of moderat views and religious attitudes (Islamic wasatiyah). This connectivity and scientific relationship can develop through study centers that provide the widest possible space for lecturers from the faculties and general and religious study programs to introduce each other's scientific characteristics, through an open minded attitude and open discussion. If supported by the right policies and firm attitude from the Rector, this scientific dialectic can be an intellectual force that has a strong carrying capacity to develop modern religious understanding and attitudes among lecturers and students.

Weakness. In certain cases and limits, the transformation of IAIN into UIN, especially the presence of faculty and general study programs along with lecturers, students and their curricula that lack religious touch can weaken the religious characteristics of UIN campuses. In turn, weakening religious characteristics will make lecturers and students not have strong religious understanding and attitudes, making it easy to be tempted by various understandings and religious attitudes present in the campus environment, including extreme religious understanding and attitudes. In some UIN, the religious characteristics of campus life are maintained by developing the Ma'had al Jami'ah program which emphasizes religious education for students. However, given the limited availability of facilities in Ma'had al Jami'ah, the ability of campus leaders to build religious characteristics is also very limited.

External Threats. In this digital era, fostering religious understanding and attitudes, other UIN and PTKI campuses faced various threats, because the sources of information and religious knowledge of the students did not only come from lecturers and textbooks, but also came through various social media 
that continued flow actively through the internet network. Social media continues to provide religious information from various sources, including from sources that introduce understanding and attitudes that are contrary to the spirit of religious moderation. Similar threats also often arise from various student organizations or extra-campus non-governmental organizations that are free to enter and leave the campus physically and digitally. In addition, efforts to prevent religious radicalism among students are also often hampered by the spread of political issues and controversial government policies, so that they can trigger a reactive and critical attitude among students.

External Opportunity. The opportunity for UIN Rector to prevent the development of religious radicalism among students is very open. This is due to the balancing information from other religious organizations, as well as from religious leaders, about the concept of moderate Islam. This balancing information is a moral energy that can make it easier for the Rector to provide understanding to students about the urgency of religious moderation in the order of the life of the nation and state. In addition, the lack of cases of religious radicalism among PTKIN students and the emergence of several cases of religious radicalism in certain PTN made the Rector of UIN have the spirit and authority to encourage public trust, including students towards the importance of religious moderation.

The UIN Rector have been able to take advantage of the various strengths they have. All Rector of UIN have utilized the authority of the religious sciences and the general sciences they have by making policies that can encourage the development of broad and moderate religious insights and attitudes among students, for example, by maximizing the role and function of Ma'had al Jami ah, developing a science integration program, and assigning lecturers in activities that foster national insight and which have to do with deradicalisation, both as administrators, participants and resource persons. Through these policies the UIN Rector not only were able toward off concerns about the threat of secularization within the UIN because of the presence of faculty and non-religious study programs, but also could encourage the development of inclusive and moderate religious understanding and attitudes. These policies are also strengthened by efforts to develop the curriculum, for example, by strengthening Pancasila courses and Nationalism Insights.

The Rector of UIN have also been able to take advantage of the various opportunities that exist to prevent the development of religious radicalism in the campus environment, by involving influential regional and national figures, to broaden the knowledge of religion and nationality through various academic activities, such as seminars, public lectures, dialogues public, and national declaration. To facilitate various academic activities, the Rector of UIN have formed a special study center which gives special attention to national issues, with relatively different names. In UIN Sunan Kalijaga Yogyakarta, for example, the Center for Pancasila and State Defense Studies has been formed.

\section{Conclusion}


In general, it can be concluded that in the view of the UIN Rector, religious radicalism is not an ideological movement, but a movement caused by a weak understanding of religion and a lack of national insight. For them, students can be exposed to religious radicalism if their religious education is not strong and their religious insights are limited. They generally believe that without extensive knowledge, understanding and religious insights, students will be upset if they face various socio-political problems, government policies and certain information that can trigger religious radicalism. It can also be concluded in this study that the various prevention policies and programs made by the UIN Rector in preventing the development of religious radicalism among students went quite effectively, through various academic and religious activities. They take advantage of the opportunities that exist and optimize the benefits of the various strengths possessed by each UIN, to streamline programs in order to prevent the development of religious radicalism among students. Most of these programs are hidden (hidden agendas) that are not explicitly linked to or labeled "prevention of religious radicalism", but contain material that can prevent the growth of religious radicalism among students.

Although there are variations in program capacity and intensity, in general the policies and programs for preventing religious radicalism among students carried out by UIN Rector have many similarities. The similarity of their policies and programs can be seen from the six main characteristics. First, preventive measures taken are academic, by prioritizing the transfer of knowledge and values, education and persuasion approaches, reactive, noncompelling and not legalistic or emphasizing sanctions or penalties. Second, the steps to prevent religious radicalism taken by UIN Rector are formal, through formal activities that have been standardized at the faculty and university levels. Third, integrated, that preventive measures are integrated with existing programs, not specific, especially exclusive. Fourth, real, not rhetorical or symbolic, that the steps to prevent religious radicalism carried out by UIN Rector are carried out in real way through various formats of activities, not just rhetoric in speeches or remarks. The steps also touch the specified target group, namely the students, not symbolized for certain students. Fifth, hidden, that steps to prevent the development of religious radicalism among students are carried out hidden or without explicit labeling, by inserting necessary materials through various student development activities. No activity was explicitly named "religious radical prevention activities". All efforts and preventive measures are implicitly entrusted in various student activities. Sixth, the policies made by the UIN Rector in preventing the development of religious radicalism among students are preventive, not reactive.

Seen from a risk management perspective, the policy taken by the UIN Rector in preventing the development of religious radicalism among students is anticipating the risk of radicalism among students. According to Hubbard (2009), risk like this is an indirect implication of speculative risk, that religious radicalism among students can happen in the future.

In general, it can also be concluded from this study that the policies and programs implemented and carried out by UIN Rector in preventing the 
development of religious radicalism among students can be said to be very effective. This effectiveness can be seen from two things. First, in the last decade there have been very few cases of religious radicalism, especially in the form of acts of violence in the name of religion, such as terrorism involving UIN students and alumni. Second, the lack of or can be said to be very minimal access to hardline religious organizations and their leaders to enter UIN campuses, both for organizing certain activities and as resource persons, due to the strong resistance of the academics. Remarkably, strong resistance did not come from UIN leaders and lecturers, but from students. Various Intra-Campus Organizations (OMIK) very often hold academic and non-academic activities that are explicitly designed as expressions of rejection of religious radicalism.

This research suggests for further study, so that there is an in-depth evaluation of the policies that have been carried out by the rectors and then raises new policy recommendations. It is also not wrong if the object of research in the future is further extended to IAIN, STAIN and also other religious Private Universities (PTS). This will later show variation in religious understanding.

\section{References}

Affandy, Sa'dullah, (2016), Akar Sejarah dan Pola Gerakan Radikalisme di Indonesia, dikutip dari website http://www.nu.or.id/post/read/69585/akar-sejarah-danpola-gerakan-radikalisme-di-indonesia

Ali, Hasanuddin, (2019), Ideologi Negara, Pancasila atau Islam, dikutip dari https://alvara-strategic.com/ideologi-negara-pancasila-atau-islam/

Asyari, Ahmad Suaidi. (2018). Review Artikel Strategi Kebijakan Pencegahan Radikalisme Beragama, Makalah pada seminar hasil penelitian, Palembang 26 Oktober.

Azra, Azyumardi. (2011). Akar Radikalisme Keagamaan, Peran Aparat Negara, Pemimpin Agama dan Guru untuk Kerukunan Umat Beragama, Makalah disampaikan pada Diskusi 'Memperkuat Toleransi Melalui Sekolah' The Habibie Center, Hotel Aston, Bogor, https://fdokumen.com/document/akarradikalisme-keagamaan-azyumardi-azra.html.

Bryson, J.M. (2005). Perencanaan Strategis bagi Organisasi Sosial. Pustaka Pelajar. Yogyakarta.

Cresswell, W, John. (1998). Qualitative Inquiry and Research Design Choosing Among Five Traditions. California: Sage Publications, Inc.

Dacholfany, M. Ihsan. (2018). Inisiasi Strategi Manajemen Lembaga Pendidikan Islam Dalam Meningkatkan Mutu Sumber Daya Manusia Islami Di Indonesia Dalam Menghadapi Era Globalisasi,Jurnal Aj-Tajdid, Volume 1 Nomor 1, 2017, http://repository.ummetro.ac.id/files/dosen/cc2f8e061f658421becf3fe90cbf6b2 6.pdf, diakses tanggal 2 November 2018/

Dja'far, Alamsyah dan Atika Nur'aini, ed., (2016), Hak Atas Kebebasan Beragama atau Keyakinan di Indonesia, Wahid Foundations, Jakarta.

Dunn, William. (1999). Pengantar Analisis Kebijakan, Yogyakarta: Gadjah Mada University Press.

Fahmi, Irfan. (2011). Manajemen Risiko, Teori, Kasus, dan Solusi, Bandung, Alfabeta 
Gupta, Sanjay., (2008). The Doctrine of Pre-emptive Strike: Application and Implications During the Administration of President George W. Bush, International Political Science Review, Volume 29, Issue 2. Website https://journals.sagepub.com/doi/abs/10.1177/0192512107085611

Handoko, Hani T., (2009). Manajemen, Edisi 2, Cetakan Keduapuluh, BPFE Yogyakarta. Hamli. (2018). Strategi Pencegahan Radikalisme di Indonesia, makalah pada kuliah umum tanggal 21 November 2018 UIN Raden Fatah, Palembang

Herero, Dolores. (2018). Tabish Khair's Just Another Jihadi Jane: Western Civilization and 'War on Terror' Versus Islamist Terrorism as the Two Sides of the Globalization Coin, Journal of Societies 8 (4), 97; https://doi.org/10.3390/soc8040097

Hubbard, Douglas. (2009). The Failure of Risk Management: Why It's Broken and How to Fix It. John Wiley \& Sons

Jati, Wasisto Rahardjo. (2013). Radicalism In The Perspective Of Islamic-Populism Trajectory Of Political Islam In Indonesia, Journal of Indonesian Islam, Volume 7, Number 02, December 2013, pp 268-287

Jonathan, Andreas, Paulus Widjaja, and Fatimah Husein. (2018). Fostering Religious Exclusivism and Political Pluralism in Indonesia Through Interfaith-based Student Community, Conference Paper, The 1st ICSEAS 2016 The 1st International Conference on South East Asia Studies, pp 53-70.

Khozin, Wahid. (2013). Sikap Keagamaan dan Potensi Radikalisme di Kalangan Mahasiswa, Jurnal Edukasi, Volume 11, Nomor 3.

Langlois, Stephanie Leman. (2005). Terorisme Old and New, Counterterorism in Canada, Police Practice and Research, Vol. 6, No. 2, May 2005, pp. 121140, Routledge Press

Maseleno, A., Huda, M., Jasmi, K. A., Basiron, B., Mustari, I., Don, A. G., \& bin Ahmad, R. (2019). Hau-Kashyap approach for student's level of expertise. Egyptian Informatics Journal, 20(1), 27-32.

Mehden, Fred R. Von Der. (2005). Radical Islam in Southeast Asia and its Challenge to U.S. Policy, James Baker III Institute for Public Policy of Rice University.

Oosterveld, Willem Theo dan Willem Bloem. (2017). The Rise and Fall of ISIS: From Evitability to Inevitability Volatility and Friction in the Age of Disintermediation, HCSS StratMon Annual Report 2016/2017, The Hague Centre for Strategis Studies, Netherland.

Rusnalasari, Zulidyana D., Hafid Algristian, Tahegga Primananda Alfath, Andini D. Arumsari, Immah Inayati. (2018). Students Vulnerability and Literacy Analysis Terrorism Ideology Prevention, 2nd International Conference on Statistics, Mathematics, Teaching, and Research, Journal of Physics: Conf. Series 1028 (2018) 012089

Saputra, Eka. (2018). Api dalam Sekam : Keberagamaan Generasi Z, PPIM UIN Jakarta, UNDP Indonesia

Saifuddin. (2011). Radikalisme Islam di Kalangan Mahasiswa, Sebuah Metamorfosa Baru, Jurnal Analisis, Volume XI, Nomor 1.

Siradj, Said Agil. (2013). The Sunni-Syiah Conflict and the Search for Peace in Indonesia, Journal of Indonesian Islam, Volume 7, Number 1, pp 145 -164 
Soleh, Badrus. (2013). The Dynamics of Muslim and Christian Relations in Ambon, Eastern Indonesia, International Journal of Business and Social Science Vol. 4 No. 3; March 2013, pp 303-311

Syam, Nur. (2018). Radikalisme Dan Masadepan Hubungan Agama-Agama: Rekonstruksi Tafsir Sosial Agama, naskah pidato pengukuhan Guru Besar pada IAIN Sunan Ampel, disampaikan tanggal 10 Oktober 2005, https://core.ac.uk/download/pdf/34212117.pdf, diakses tanggal 24 Oktober 2018.

Wirsing, Robert .(2004). Religion, Radicalism, and Security in South Asia, in Religious Radicalism And Security In South Asia, edited by Satu P. Limaye, Mohan Malik, Robert G. Wirsing, Asia-Pacific Center for Security Studies, pp 1-16

Wiktorowicz, Quintan, (2005), A Genealogy of Radical Islam, Study in Conflict and Terorism, $\quad$ Volume 28 Website http://insct.syr.edu/wpcontent/uploads/2013/03/Wicktorovitcz.2005.Geneology-of-Radical-Islam.pdf

Zada, Khamami, (2009), Radikalisme di Jantung Pendidikan Islam, Jurnal Penelitian Pendidikan Agama dan Pendidikan Keagamaan, Volume 7, Nomor 4, Oktober-Desember 2009, website http://download.garuda.ristekdikti.go.id/ article.php? article $=518912 \& \mathrm{val}=10615 \&$ title $=$ RADIKALISME\%20DI\%20JA NTUNG\%20PENDIDIKAN\%20ISLAM

Zainiyati, Husniyatus Salamah. (2016). Curriculum, Islamic Understanding And Radical Islamic Movements In Indonesia, Journal of Indonesian Islam, Volume 10, Number 2, December, pp 285-308 